\title{
THE NECESSITY OF AN EFFECTIVE STUDY APPROACH IN DOCTORAL EDUCATION
}

\author{
Iluta Arbidane ${ }^{1}$, Nonna Khachatryan ${ }^{2}$, Daina Znotina ${ }^{3}$ \\ ${ }^{1}$ Dr.oec., associate professor, leading researcher, Rezekne Academy of \\ Technologies, Rezekne, Latvia, e-mail: Iluta.Arbidane@rta.lv \\ 2 Dr.oec., associate professor, Yerevan State University, Yerevan, Armenia, \\ e-mail: nonnakhachatryan@yahoo.com \\ ${ }^{3}$ Mg.soc.sc., lecturer, researcher, Rezekne Academy of Technologies, Rezekne, \\ Latvia, e-mail: Daina.Znotina@rta.lv
}

\begin{abstract}
The aim of the paper is to analyse various research studies in regard to teaching strategy in PhD programmes within the Bologna education area and to give recommendations aimed at the development of educational process structuring in the third level of higher education. Novelty of the research - an analysis on the effective implementation of doctoral studies was conducted, emphasizing the implementation of them in Latvia and Armenia. Research methods - analysis of documents, logical construction and the graphical method. The paper discusses the effective approaches of PhD programmes to teaching strategies that are focused on formation of outcomes, such as interpersonal and leadership skills, project management and organization, research and information management, self-management and career development. Nowadays, it is highly important to remodel the educational strategy, targeted at the PhD student's transferable skills acquisition, through avoiding unnecessary theoretical educational modules and academic training pressure.
\end{abstract}

Keywords: competitive learning outcomes, doctoral studies, Salzburg principles, transferable skills of a PhD student.

JEL code: $125,03$.

\section{Introduction}

Doctoral education is fundamentally different from the teaching-based first and second cycle. It is highly individual; doctoral candidates do not follow a predictable path, which is carved out in successive modules, but they follow a hypothesis or an idea leading them to uncharted territory, which they must then learn to navigate (Quality Assurance ..., 2013). In doing research, doctoral candidates sometimes are so unwilling to attend the lecturing process and various module examinations; mostly they are eager to finalize the research and move on to final defence. On the other hand, the doctorate is presented not only as research, but also as an educational process, and consequently needs effective teaching strategy implementation.

The aim of the paper is to analyse various studies in regard to teaching strategy in $\mathrm{PhD}$ programmes within the Bologna education area and to give recommendations aimed at the development of educational process structuring in the third level of higher education. 
Tasks of the research are to: 1) highlight the importance of doctoral studies in social and economic development; 2) identify the organization of doctoral studies in Latvia and Armenia; 3) draw conclusions and make proposals. Novelty of the research - an analysis conducted on the issues of effective implementation of doctoral studies, emphasizing the implementation of them in Latvia and Armenia. Research methods - analysis of the documents, as well as logical construction and the graphical method.

While writing this paper, the following previous researches have been studied: Eurodoc Survey I (2009), Quality Assurance in Doctoral Education the results of the ARDE project (2013), World Bank report "Latvian doctoral studies and the promotion system" (2016), Akadēmiskā karjera Latvijā: ieteikumi (2018) (Academic career in Latvia: suggestions (2018), Doctoral education in Europe today: approaches and institutional structures (2019).

\section{Importance of doctoral level studies in social and economic development}

Doctoral education is often described as the bridge between research and education, thus also the essential link between the European Higher Education and Research Areas. Universities across the continent have the main responsibility for providing training both in and through research. As the main component of the doctorate is the original research performed by each doctoral candidate, doctoral education cannot be considered and evaluated in the same way as Bachelor and Master programmes (Latvian doctoral ..., 2016). It is now widely recognised that doctoral graduates make significant contributions to innovation and that they need both a thorough and broad skill set to do so. With many graduates gaining employment outside of academia, the tradition of doctoral training only for replenishment of academia belongs to the past. This recognition has resulted in the growth of structured doctorates and institutional structures to ensure breadth and consistency of training at universities (Maintaining a quality ..., 2014).

In this regard, the question arises: at which areas reforms in the doctoral study process should be targeted, which will promote social and economic development of the society. On the one hand, the $\mathrm{PhD}$ is assisting in the development of professional careers of researchers, giving them more opportunities for taking high level job positions in the labour market. But at same time, not often they are consistent followers of research novelties and their implementation process and in that event, the scientific results do not actively promote social and economic development of the society, and are mainly "outstanding on the paper", formatting the cycle for "the development of science for the benefit of science". 
One of the main tasks of researchers is to focus on continuous improvement of their research skills and competences. A number of studies suggest that doctoral degree holders' personal career progress is significantly faster than that of other degree holders. However, many universities are quite aware that the transition from the academic to nonacademic labour market could be made easier and doctoral candidates should be prepared for the transition from an early point onward (Quality Assurance ..., 2013). Therefore, in addition to research skills, the appropriate development of transversal or transferable (also known as 'generic') skills and competences is needed (Doctoral education, 2019).

A question arises: why to prepare many doctors instead of preparing specialists who would be in great demand in the local and international labour markets? Why not to conduct a needs assessment to find out the most demanding specialties and not the most fashionable ones? How to implement international experience and good practices in the education system? (Yeritsyan et al., 2015).

The doctoral study process should more relate to the Salzburg principles (Promoting Internationalization..., 2005) operating within the Bologna process. However, the set of standards for establishing and implementing an efficient third cycle are as follows:

- the core components of doctoral training is the advancement of knowledge through original research,

- embedding of institutional strategies and policies aimed at operating $\mathrm{PhD}$ programmes towards society development promotion,

- recognition of doctoral candidates as early stage researchers,

- creation of linkage between PhD programmes and scientific-labour markets.

The number of doctoral candidates successfully completing their studies should make more positive impact not only on personal carrier progress, but also on the society development. As a result of $\mathrm{PhD}$ candidates successfully completing their degrees, it is expected that far more trained researchers than before will seek and will have to seek job outside academia and research institutions. The relevance of research topics and the achievement of additional transferable skills, abilities for non-academic labour markets, currently became key challenges in doctoral education.

Surveys conducted among doctoral students in the universities of the Western European countries show that more than a third of them prefer to work on the dissertation, spending more than 21 hours a week in this area (see Table 1). That is, they are seeking their doctoral studies in educational subjects and be unloaded, more involved in research activities. 
Lecturing on professional skills in $\mathrm{PhD}$ studies gives some space for discussions conditioned upon the existence of the graduate's skills obtained during previous degree studies. A question is raised: what additional skills a doctoral student needs that s/he did not obtain during master's or bachelor's studies. Without "pre-training of master's students", it would have been difficult to obtain research, pedagogical or management skills in PhD studies since, first of all, the doctoral student/applicant should be familiar with those, and then should obtain creative transferable skills.

Table 1 How many hours a week do you spend on working on the thesis? (\%) (Eurodoc Survey I, 2009)

\begin{tabular}{|l|r|r|r|r|r|r|r|}
\hline Country & \multicolumn{1}{c|}{0} & \multicolumn{1}{c|}{$1-5$} & \multicolumn{1}{c|}{$6-10$} & $11-15$ & $16-20$ & $\begin{array}{l}\text { More than 21 } \\
\text { hours }\end{array}$ & Respondents \\
\hline Austria & 20.8 & 15.6 & 17.7 & 5.7 & 4.9 & 35.2 & 610 \\
\hline Belgium & 27.9 & 11.6 & 14.3 & 6.3 & 6.3 & 33.6 & 301 \\
\hline Croatia & 26.2 & 6.8 & 16.7 & 4.0 & 5.6 & 40.7 & 324 \\
\hline Finland & 22.0 & 9.8 & 17.0 & 8.7 & 10.6 & 32.0 & 654 \\
\hline France & 17.6 & 9.2 & 12.2 & 6.0 & 5.9 & 49.1 & 1124 \\
\hline Germany & 18.6 & 11.2 & 18.2 & 5.9 & 8.3 & 37.7 & 1165 \\
\hline Holland & 24.0 & 11.3 & 20.1 & 4.5 & 9.3 & 30.9 & 583 \\
\hline Norway & 22.0 & 10.1 & 17.6 & 9.0 & 7.2 & 34.2 & 755 \\
\hline Sweden & 28.1 & 9.2 & 15.5 & 5.1 & 5.7 & 36.5 & 491 \\
\hline
\end{tabular}

A PhD studies graduate must have full professional skills in scientific, educational, management, innovation generation fields, and thus should master such professional skills which will be transferrable from science to pedagogy, or from pedagogy to leadership. Thus, transferrable skills are universal and are of importance in utilization of professional skills of a doctoral student in all the fields. This is the reason that doctoral students are taught more transferrable skills rather than professional skills (See Fig.1).

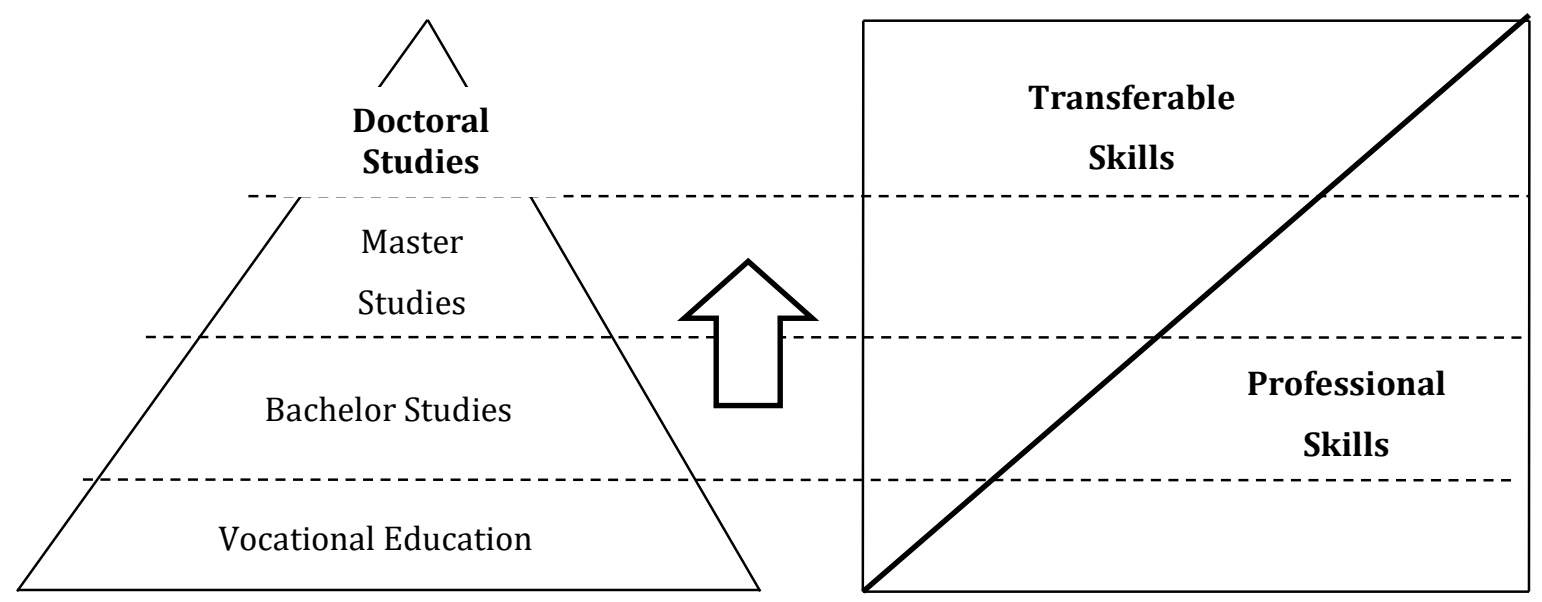

Fig. 1 The process of transferrable skills formation at different stages of vocational education (created by the authors) 
The range of transferable skills for the outcomes of doctoral education in various universities are different, but in general they are summarized in the following groups:

- Analysis and Problem-Solving (Define a problem and identify possible causes. Comprehend a large amount of information. Form and defend independent conclusions).

- Interpersonal and Leadership Skills (Facilitate group discussions or conduct meetings. Motivate others to complete projects (group or individual). Respond appropriately to positive or negative feedback. Effectively mentor subordinates and/or peers).

- Project Management and Organization (Identify goals and/or tasks to be accomplished and a realistic timeline for completion. Prioritize tasks while anticipating potential problems. Maintain flexibility in the face of changing circumstances).

- Research and Information Management (Identify sources of information applicable to a given problem. Understand and synthesize large quantities of data. Design and analyse surveys).

- Self-Management and Work Habits (Work effectively under pressure and to meet deadlines. Comprehend new material and subject matter quickly. Work effectively with limited supervision).

- Written and Oral Communication (Prepare concise and logicallywritten materials. Write at all levels - a brief abstract to a book-length manuscript. Explain complex or difficult concepts in basic terms and language. Write effective grant proposals) (PhD transferable skills).

In comparison, $\mathrm{PhD}$ studies differ from previous educational systems with the fact that they provide the graduate with transferrable skills (see Figure 2), in the basis of which the following characteristics can be found:

- high level of self-management,

- high level of creative activities,

- flexibility of decision making,

- quality criteria of research analysis.

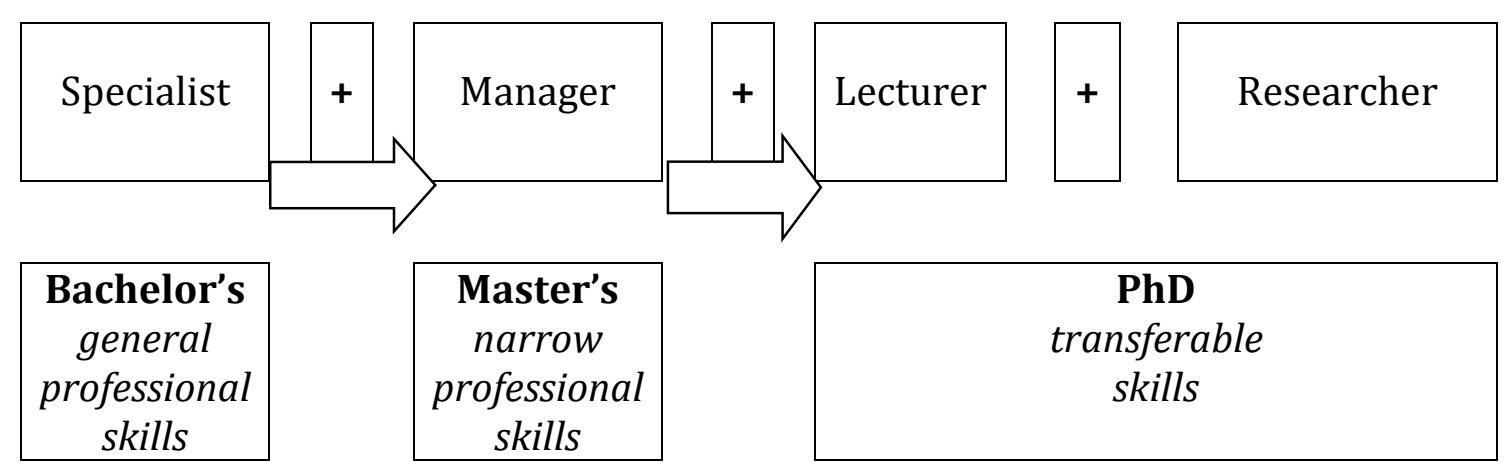

Fig. 2 The formation process of qualitative characteristics of a PhD student at the educational levels of HEIs (created by the authors) 
The formation of a creative way of thinking among students must also be considered a milestone of competitiveness increase in vocational education. A mechanical understanding of things prevails among some students and professors when education is mainly considered as an activity of transferring knowledge with the aim to later check it through an examination.

\section{Topicalities of doctoral studies in Latvia}

In the World Bank's research on doctoral studies and the promotion system in Latvia, conducted in 2016 (Latvian doctoral..., 2016), it was concluded that institutions offer relatively good conditions for their students; the administration and staff showed commitment to student success, and students were clearly motivated despite their difficult financial situation. The monthly State stipend (EUR 113) does not allow students to focus full time on their doctoral studies because most of them need to work to cover their living expenses. The process of grant proposals is not launched every year, which means that research funding goes through cycles and it is difficult to plan the intake of doctoral students; in some cases, the students would have to change their research topic if the grant supporting them has ended before they were finished. Unsurprisingly, the system fails to attract international students. In addition, because most of the Latvian students are working, it takes longer than planned for them to complete their doctoral works. The allocation for doctoral students is three times higher than the allocation for undergraduate students. Like in various other middle-income countries, Latvian industrial R\&D capacity is reported not to be very strong; concerns were expressed that doctoral training was undervalued by industry and the opportunities for collaborative doctorates were rare; there was no evidence of transferable skills development offered by the universities; the promotion process was very complex.

The Government of Latvia has identified the improvement of doctoral studies and the promotion system as a key national priority. In addition to increasing the number of doctoral candidates, the government set the following objectives: 1) improvement of the promotion process; 2) involvement of the doctoral students in scientific projects; 3) establishing scholarships for excellent doctoral students with high research potential; 4) preparation of master students and doctoral students for specific industrial partners; allocate the state budget subsidy for respective master and doctoral studies as priority areas; 5) moving towards a joint system of doctoral studies (common quality principles); 6) strengthening the link between doctoral studies and research and industry, formation of doctoral 
centres in Latvia, support for the renovation of infrastructure, etc. (World Bank, 2016).

Getting a $\mathrm{PhD}$ is a prerequisite for starting an academic career; therefore it is a stage that every academic staff member has to go through. Thus, doctoral studies are the key for promoting not only the quality of academic careers, but also the quality of science and of the higher education system as a whole. In addition, many $\mathrm{PhD}$ graduates hold important positions in society or in the field of economics; therefore doctoral studies are highly important for social and economic development. In order to achieve the goal of high quality of doctoral studies in Latvia, as well as to establish stable postdoctoral programmes, there is a need for coherence between the higher education institutions responsible for this objective and the government responsible for adopting the legal framework. For example, since there is necessity for stable institutionalization, the government must give institutions discretion in setting up institutional structures and programmes, as well as must stimulate them for continued development. Higher education institutions should use the autonomy granted to them and pursue doctoral studies in a way that focuses on the conditions necessary to prepare doctoral students for careers both in and outside the academic environment (Akadēmiskā karjera Latvijā: ieteikumi (2018). A working group responsible for development issues of the doctoral level studies and promotion system started its work in the Ministry of Education and Science on May 29, 2019.

According to the Government Plan, the working group must elaborate proposals for a new doctoral model according to international standards (Salzburg Principles) by the end of 2019, as well as must participate in the preparation of an information report and propose amendments to related regulations (Starting proposals..., 2019).

\section{Topicalities of doctoral studies in Armenia}

At present Armenia's higher education system reforms in the context of doctoral education face serious challenges. Third level education within the Bologna Process associated with the Salzburg principles is not currently applied completely. Moreover, Armenia is still under the impact of the postgraduate education approaches inherited from the Soviet Union, and, as a result, any assessment of outcomes of a high-quality researcher, aimed at the labour market, is not of importance. Traditionally, Armenia is considered a country with a higher level of educated population and variety of scientists. But even at this condition, implementation of research and practice activity of researchers has not made serious impact on social and economic development of the society. Functions of several substantial scientific organizations, mostly operating from public financing sources, should be 
represented with effective outcomes from research. However, the main reasons of this situation relate to ineffective organizational issues of $\mathrm{PhD}$ education in Armenia.

Studies show that currently in Armenia, most of the doctoral students are:

- educated and trained too narrowly,

- lacking key professional skills,

- poorly prepared to teach,

- taking too long to complete their degree or do not complete it at all,

- having an overly long transition period from PhD completion to stable employment (Tshuguryan, 2015).

The educational environment in doctoral studies in Armenia is not competitive yet. There are linkages between $\mathrm{PhD}$ programmes and the labour market. Furthermore, the research programmes do not strongly relate to contemporary demands of economic development, and only a few of them are functioning based on contracts between universities, research centres and business organizations. As a result, mainly a process by format is taking place, "creating science for scientific necessities", but not "science for social and economic development". Besides, the absence of the science market does not give opportunities for commercialization of research results, finding stable financial sources for develoing $\mathrm{PhD}$ programmes and presenting competitive doctoral study programmes in Armenia.

Although postgraduate education in Armenian universities has traditionally been operating, based on the principles of Soviet "aspirantura", they are applied on inertial motion. Thus, the research block still dominates in them, but the educational block is still at the formation stage. Previously, candidates did not need to earn academic credits and they were generally overwhelmed by research work. However, now a post-graduate student has to earn academic credits not only from the research sphere, but also from the educational block, regularly attending courses. In the current situation, joint doctoral programmes are not formed, there is no framework of providing educational services, which is one of the most important Salzburg principles.

Traditionally, "aspirantura" was not in close cooperation with the labour market. Postgraduate students used to perform research work without being involved in production, and as a result, there were no commercial orders from the sphere of production and service practice fields. The situation is similar for postgraduate studies functioning in Armenian Universities, which do not have close relationship to the applied economy; they were deprived from employers' orders and private financial inflows. It turns out that postgraduate studies are financed only by public means, i.e. from the State budget, which is not enough for a stable cash flow, and this is considered to be one of the most important Salzburg principles. 
In case of postgraduate studies, academic freedoms are still constrained, which is specially highlighted during the process of preparation and defence of a dissertation thesis. The postgraduate education system does not have full academic freedom to approve theses, as the final titles of the theses are approved by the scientific councils of universities.

In addition, thesis defence process bureaucracy is overly inflated. First, a doctorate student defends a thesis at the University Chair, then in a leading organization, and finally before a Professorial Council, but, in fact, not all the professors deal with a narrow specialization of a thesis within this council. After passing this three-step defence procedure, a PhD student can fail at the Supreme Certifying Commission. This will lead to a second defence.

According to experts, in Armenian universities, a doctoral thesis is often a review paper, derived from books in Armenian or Russian, rather than an original work of independent research. According to statistics, over 45\% qualified scientists and researchers have left Armenia in the past twenty years seeking better quality research environments outside (Implementation of Salzburg ..., 2015).

\section{Conclusions and suggestions}

Sometimes the educational process is still considered by a part of lectures and students as a way to obtain knowledge rather than a process directed to develop a way of thinking.

Nowadays competitive are those educational programmes of the third cycle of higher education, through the final outcomes of which not only "competent" graduates, but also ones with "creative skills" are formed. In this regard, great attention in educational programmes should be paid to the outcomes of efficient personal work with the aim of developing creativity, innovation and self-expression of a learner, which is one of the requirements of the Bologna process.

Postgraduate education is taking more discussion within Bologna process development in the European Higher Education Area as a whole. The main discussions focus on the following: which are the most important targets in doctoral studies - whether to prepare researchers with transferable skills, or to make original research and present a dissertation with scientific novelties. These issues closely relate to implementation of the Salzburg principles for the third cycle of vocational education, taking the doctoral training as an advancement of knowledge through original research. At the same time, it is recognized that doctoral training must increasingly meet the needs of the market that is wider than academia.

While the Armenian higher education system battles for improvements within the realm of third cycle studies to find the most adequate ways to 
incorporate quality research in doctoral education, throughout Europe battles and transformation have occurred just the same way. It has been noted that the change in focus on doctoral education from the research output, the thesis, to the doctoral degree holder has been fundamental in the development of career services. The outcome is no longer the research results to be defended in front of an expert panel, and the doctorate holder with specific research, transferable skills and experience, should be represented in a wide range of careers.

\section{References}

1. Akadēmiskā karjera Latvijā: ieteikumi (2018). Retrieved from https://izm.gov.lv/images/izglitiba_augst/Pasaules_Banka/Akadmisk-karjeraLatvij-ieteikumi.pdf

2. Doctoral education in Europe today: approaches and institutional structures (2019). SURVEY. Retrieved from https://eua.eu/downloads/publications/online\% 20eua\%20cde\%20survey\%2016.01.2019.pdf

3. Eurodoc Survey I (2009). Descriptive Report, p. 77.

4. Implementation of Salzburg principles in the Republic of Armenia (2015). EU-funded Tempus VERITAS Project, Yerevan, p. 28.

5. Yeritsyan, S., Tshuguryan, A. (2015). Bologna Process consequence Pathway. Yerevan, p. 74.

6. Latvian doctoral studies and promotion system (2016). Washington, DC: World Bank. Retrieved from https://www.izm.gov.lv/images/izglitiba_augst/ Pasaules_Banka/Latvian_doctoral_studies_and_promotion_system.pdf

7. Maintaining a quality culture in doctoral education at research - intensive universities (2014). LERU. Retrieved from https://www.leru.org/files/ Maintaining-a-Quality-Culture-in-Doctoral-Education-Full-paper.pdf

8. PhD transferable skills (n.d.). University of Michigan. Retrieved from https://careercenter.umich.edu/article/phd-transferable-skills

9. Promoting Internationalization of Research through Establishment and Operationalization of Cycle 3 Quality Assurance System in Line with the European Integration (2005). Retrieved from http://c3qa.iqaa.kz/en/project-documents/ salzburg-principles

10. Quality Assurance in Doctoral Education-results of the ARDE project (2013). EUA publications, 2013, p. 8.

11. Sākas priekšlikumu izstrāde jaunam doktora līmeṇu studiju un promocijas sistēmas modelim (2019). Retrieved from https://www.izm.gov.lv/lv/aktualitates/3518sakas-priekslikumu-izstrade-jaunam-doktora-limenu-studiju-un-promocijassistemas-modelim

12. Tshuguryan, A. (2015). Challenges in post-graduate education organization in Armenia. Messenger of Armenian State University of Economics, 3(39), Yerevan, pp. 152-154. 